\title{
Developing e-Booklet Based on Hair Trimming Video for Blended Learning
}

\author{
Rohana Aritonang ${ }^{1}$ Irmiah Nurul Rangkuti ${ }^{2,}{ }^{*}$ Vita Pujawanti Dhana ${ }^{3}$ \\ ${ }^{1,2,3}$ Cosmetology Department, Bachelor Degree, Univeristas Negeri Medan, Medan, Indonesia \\ *Corresponding author. Email: missirmiahnurul@gmail.com
}

\begin{abstract}
This study aims to: (1) Develop e-Booklet base on Hair Trimming Video for Blended Learning, (2) to examine the optimization of blended learning learning models using e-booklet and hair trimming videos. This type of research is development research using the Borg \& Gall model combined with the blended learning model. The data collected were analyzed using qualitative descriptive analysis techniques. The results of hypothesis testing prove that: (1) The e-booklet and learning video are suitable for use in learning, (2) there is a significant difference between the blended learning outcomes of students who taught using the e-booklet and hair trimming learning videos. This is indicated by the results of data processing and it is concluded that the use of e- booklet based on Hair Trimming Learning Videos for blended learning are more optimal in increasing the competence and knowledge of students in Hair trimming Learning.
\end{abstract}

Keywords: Blended Learning- Hair Trimming- e-booklet-video.

\section{INTRODUCTION}

The concept of online or e-learning influences the transformation of conventional education into digital form, both in content and system. The function of the application of e-learning can be as an addition or complement / support (complement) or as a substitute (substitution) conventional learning (Siahaan, 2001). Based on this understanding, in this era of digitalization, the world of education took a role by presenting various learning models that use digital technology. The transformation of conventional education towards digital ones becomes an important thing that is taken into account in measuring the progress of education. Of course, not only the improvement of human resources that are increasingly developed or advanced, but also strategies / models / methods / techniques / learning tactics.

The emergence of pandemics around the world has changed a lot. Universities throughout Indonesia are faced with the presence of the industrial revolution era 4.0 which successfully disrupted conventional learning models in the form of face-to-face. Currently, learning is expected to combine conventional learning and online learning known as blended learning. The application of blended learning model is one form of improvement of science and technology development and innovation in the field of education. Based on data from the Directorate General of Learning and Student Affairs Kemenristekdikti (2018) revealed that the use of mixed learning is very in line with the learning style of millennials and provides opportunities for students to take advantage of the use of information technology to conduct big data-based information tracing. The use of mixed learning for students will strengthen digital literacy and technology literacy, of course this is very in line with the demands of the industrial revolution era 4.0. In addition, according to Tantri (2018) social presence in online learning is strongly associated with one of the elements to achieve meaningful learning success.

The switch of conventional learning into a blended learning system requires lecturers as facilitators of learning to be more creative in delivering learning materials. The existence of electronic media can help in the learning process, no exception in the defense of Hair Trimming learning. Lecturers feel the need to create learning innovations that fit the online learning model and can be accessed at any time according to the needs of students. Media e-booklets and e-booklets and learning videos are the most suitable media to help strengthen the blended learning system. With the media e-booklet and video learning basic hair trimming. Lecturers can be easier in explaining the material and minimizing the validity of the material taught. E-booklets designed with 
a variety of images and colors can represent basic hair trimming materials filled with colors and images. The ebooklet can also explain in detail the basic stages of trimming hair. While the e-booklet and learning video contains about the material explanation in a more concrete way by explaining each technique of basic hair trimming. Based on this, researchers are interested in innovating learning by developing e-Booklet based on Hair Trimming Video for Blended Learning.

\section{THEORETICAL STUDIES}

\subsection{Understanding of development}

Development is an effort to improve technical, theoretical, conceptual, and moral skills according to needs through education and training. Development is a process of designing learning logically, and systematically in order to establish everything that will be implemented in the process of learning activities by paying attention to the potential and competence of learners. So, the development of learning is more realistic, not just educational idealism that is difficult to apply in life. Learning development is an effort to improve the quality of the learning process, both materially and methodically and substitution. Materially, it means from the aspect of teaching materials that are adapted to the development of knowledge, while methodologically and substance related to the development of learning strategies, both theoretically and practically.

Development research are steps to develop a new product or improve an existing product, which can be accounted for. The purpose of this research is to produce new products through development. Based on the understanding of development that has been described what is meant by development is a process to make the existing potential into something better and useful while research and development is a process or steps to develop a product or improve an existing product into a product that can be accounted for.

\subsection{E-booklet and Video media}

\subsubsection{Definition of e-booklet and video media.}

According to the Great Dictionary of Indonesian Language (KBBI): buk.let /buklét/ $\mathrm{n}$ a small book that serves as a flyer: -- it contains how to cook and menu for Lebaran. E-booklet is a communication media that belongs to the category of media below the line media. According to the nature attached to the bottom-line media, the message written on the media is guided by several criteria, namely: using short sentences, simple, short, concise, using uppercase and bold letters. In addition, 50 letters use no less than $10 \mathrm{pt}$, packaged interesting and economically used words (Suleman in Cindy, 2013).
According to Ewles (in Cindy, 2013) e-booklet media has advantages, namely clients can adjust from selflearning, users can see the content at a leisurely time, information can be shared with family and friends, easy to make, reduce the need to take notes, can be made simply at a relatively low cost, durable, tamping power more widely, can be directed at a certain segment. Similarly, the opinion in Chusnul Khotimah (2015) can be concluded that the e-booklet is a medium of communication in the form of a booklet, which contains information.

In the manufacture of good media, there are media characteristics that can be seen easily, as for the characteristics of e-booklets are:

a. Judging by the form of an e-booklet:

- Small printed sheets of paper.

- Neatly arranged in the form of a book.

- Writing consists of $200 \pm 400$ letters with printed writing, usually with interspersed pictures.

- The size is usually $20 \pm 30 \mathrm{~cm}$.

b. Judging by the content, there are interesting pictures and writings on the e-booklet

c. The things that must be considered in the manufacture of e-booklets, namely:

- Determine the target group you want to achieve.

- Write down what the purpose is.

- Determine the brief content of things to be written in the e-booklet.

- Gather about the subject to be delivered.

- Outline the way the message is presented, including how the text, drawing, and layout form.

- Create the concept,

- The concept of being tied first to the target group is almost the same as the target group.

- Refine the concept and create an illustration that matches the content.

From the above understanding, it can be concluded that e-booklet is a medium of electronic books with a small size arranged in the form of books, containing information that is disseminated to the public easily.

E-booklets shaped like electronic books have several principles in their manufacture, this is stated by Aqib (2013:52): a. Visible is to load content that is easy to see. b. Interesting i.e. interesting. c. Simple is simple. d. Useful is useful for educational resources e. Accourate is right and on target. f.Legitimate is valid and reasonable. g. Structured is well organized and . Meanwhile, in another point of view, Prastowo (2012) suggests there is a technique of preparing e-booklet media which is a print educational media with the following steps: a. The titles and materials presented are based on the achievement of 
basic competencies or student materials. b. Contains a language that is easy to understand according to the development of the target language of its users. c. Able to test students' understanding of something. d. The existence of stimulants is related to the comfort and absence of a display that encourages the reader to explore it. e. Ease of reading is related to the friendliness of print materials when faced with eyes such as thin, font size, color, and type of paper.

From the various descriptions above about the understanding of e-booklets and also techniques used in the creation of books according to experts can be concluded that e-booklet is a medium of books in the form of print media therefore the workings of e-booklets fall into the category of visual media that is not projected or two-dimensional. Moreover, the use of e-booklet media is especially for early childhood, where children are more interested in a book in which some of the more images with interesting color compositions.

\subsection{Hair trimming}

\subsubsection{Definition of Hair Trimming}

In "ethymology", the word pruning consists of the word "trim" which means cut, so pruning is the act of cutting which in the world of beauty the act of trimming hair. The definition of pruning can be interpreted as an action to reduce the length of the original hair with certain techniques, adapted to the shape of the face, hair type, care, occupation and personality of a person so as to produce the model of trim desired by a person.

The purpose of pruning include: embellishing the shape of the head; make hair arrangement easier; give the impression of an oval face; sharpen the face lines; prevent hair from falling in front of the face; and follow the current model and so on.

\subsubsection{Hair Trimming Pattern.}

Hair Trimming Line Pattern consists of 5 archetypes, namely:

- Solid Trimming Pattern. Flat / Solid pattern (trim neutral angle cut), giving the hair a horizontal line shape that makes the hair look flat and equal in length and does not form a certain angle The direction of the trim starts from the back to the front. So with this neutral trimming pattern can be made a model of pruning commonly called Page Boy (Solid Parallel).

- Oval Trimming Pattern. The Circumference / oval pattern is essentially an ascending pattern that is made to connect up to the forehead. The trimming direction extends behind and shortens on the front resulting in a rounded or oval circle. One of vidal Sasson's creations is "The Halo".

- Front Diagonal Trimming Pattern. The pattern is down (solid diagonal forward), resulting in a shortened trim from the back and elongating on the front and forming an angle to the two front sides. If this trim is seen from the back of the design direction this will appear to decrease. Vidal Sasson is named The Long Geometric Cut.

- Back Diagonal Trimming Pattern. The pattern rises (solid diagonally backwards), resulting in an elongated trim from the back and continuing to shorten to the front. According to Charless Ross is known as the trim of The Minus Angle cut.

\subsubsection{Hair trimming tools and their use techniques}

Hair trimming tools are specifically grouped into large tools commonly called furniture and hand tools that are small tools used to do hair trimming. Various hair trimming tools can be used, provided that they meet the minimum standards of need, feasibility and safety of use.

Large furniture or tools include: dressing table; trim chair; troly; and trash cans. Hand tools include: a. Cut Scissors 1) Cut Blades Scissors One 41/2" To trim hair in general, trap (graduation / layer) and for the angle of trim. $5 "$ To trim the trim line straight. 51/2" To trim the curved trim line. Thinning Scissors Thinning scissors are used to reduce the volume of hair, reduce the thickness and density of hair, have different tooth sizes according to the desired trim design.

\section{RESULTS AND DISCUSSION}

The results showed: (1) e-booklet media and learning videos are eligible for use in basic hair trimming learning in the education program of tata arias universitas negeri medan, (2) there is a significant difference between student learning outcomes that are studied using ebooklet media and learning videos.

This is indicated by the results of data processing (tcount $=3,285$ ) at the level of significance $0=0.05$ with $\mathrm{dk} 56$ obtained (ttable $=1.67$ ), so (tcount $>$ ttable), effectiveness of the use of e-booklet media and learning videos of basic hair trimming $=80.46 \%$. The study results of the group of students who were studied without using e-booklet media and basic hair trimming learning videos by $71.72 \%$. From this data proves that the use of ebooklet media and basic hair trimming learning videos are more effective in improving students' competence and knowledge on basic hair trimming learning than without using e-booklet media and learning videos.

\section{CONCLUSION}

Based on the results obtained from this study, it can be concluded the e-booklet and learning video are suitable for use in learning and there is a significant difference between the blended learning outcomes of students who taught using the e-booklet and hair trimming learning videos. This is indicated by the results of data processing and it is concluded that the use of e- 
booklet based on Hair Trimming Learning Videos for blended learning are more optimal in increasing the competence and knowledge of students in Hair trimming Learning.

\section{REFERENCES}

[1] Borg, W.R \& M.D. Gall. 1983. Educational Research: An Introduction, New York: Longman,Inc.

[2] Dick, W, Carey, L \& Carey, O. 2005. Systematic Design of Instructional (5th ed). New York: Addison-Wesley Educational Publisher Educational Technology Publicational, Inc.

[3] Gerlach Vernon. S, Elly Donald.P. 1980. Teaching \& Media a Systematic Approach, New Jersey: Prentice Hall.

[4] Hadisuwarno, Rudi .2015. Pemangkasan Rambut Dasar, Jakarta: Gramedia Pustaka.

[5] Kustanti, Herni dkk, (2008), Tata Kecantikan Kulit Direktorat Pengembangan SMK. Jakarta: Depdiknas.

[6] Miarso, Yusufhadi. 2004. Menyemai Benih Teknologi Pendidikan, Jakarta: Prenada Media dan Pustekkon Diknas.

[7] Paningkiran, Halim. 2013. RiasPengantin Indonesia. Jakarta. Gramedia Pustaka Utama.

[8] Rusijino, dkk. 2008. Penelitian Teknologi Pembelajaran, Surabaya: Unesa University Press.

[9] Seels, B.B. \& Richey, R.C. 1994. Instructional Technology: The definition and Domains of Field, Terjemahan Dewi S Prawiradilaga, R. Rahardjo, Yusufhadi Miarso, Jakarta: IPTPI\& LPTK).

[10] Sukiman, 2012, Pengembangan Bahan Ajar Pembelajaran, Yogyakarta: Pustaka Insan Madani.

[11] Sudjana. 2009. Metoda Statistika, Bandung: Tarsito.

[12] Sudijono, Anas. 2009. Pengantar Statistik Pendidikan, Jakarta: Raja Grafindo Persada 